\title{
The Commentary Tradition on Aristotle's De generatione et corruptione. An Introductory Survey
}

\author{
Johannes M. M. H. Thijssen
}

When discussing the medieval curriculum in natural philosophy, James Weisheipl once observed that "few bothered to deal with ... De generatione et corruptione." 1 This observation, however, seems to reflect the current low interest in this work rather than the activities of past commentators. For many ancient, medieval and Renaissance authors wrote commentaries on the De generatione et corruptione, among them famous thinkers such as John Philoponus, Albert the Great, Thomas Aquinas, John Buridan, Nicole Oresme, Biagio de Parma, Paulus Venetus, Pietro Pomponazzi, Francescus Toletus, the Coimbra commentators, Francesco Piccolomini, Jacopo Zabarella, Caesar Cremonini, and Galileo Galilei. ${ }^{2}$ By contrast, De generatione et corruptione remains today probably one of the least studied among Aristotle's treatises in natural philosophy, a disreputable position which it shares with the commentary literature dedicated to it. ${ }^{3}$ The present article cannot remedy this deficiency. All that it can do is to recall some well-known and lesser-known facts about the transmission and study of Aristotle's De generatione et corruptione in the West and to provide a few suggestions for further research.

1. Weisheipl, “The Interpretation of Aristotle's Physics," p. 523. More recently, during a plenary discussion at a conference devoted to the curriculum of the arts faculty at Paris, Louis Jacques Bataillon observed: "je voudrais plaider pour des mal-aimés [dans les textes d'Aristote]. En premier lieu, le De generatione et corruptione et le [quatrième] livre des Météores.” His observation originated from the fact that the conference virtually ignored discussing the place of the De generatione et corruptione in the curriculum. See Weijers e.a. (eds.), L'enseignement des disciplines, p. 329.

2. A survey of the commentaries is provided by Charles Lohr in his Medieval Latin Aristotle Commentaries, and his Latin Aristotle Commentaries, vol. II. Renaissance Authors. An updated chronological list of commentators on De generatione et corruptione, which prof. Lohr has kindly put at my disposal, shows some interesting patterns. During the thirteenth, fourteenth, and fifteenth centuries, approximately fifteen authors per century wrote one or several commentaries on De generatione et corruptione. During the sixteenth and seventeenth centuries, this figure dramatically rose to about a hundred commentators. For Galileo's questions on Aristotle's De generatione et corruptione, see Wallace, Galileo's Early Notebooks, esp. pp. 159-253.

3. Interestingly, the 1999 Symposium Aristotelicum is devoted to Book 1 of Aristotle's De generatione et corruptione. Its proceedings will be edited by Jaap Mansfeld and will be published at Oxford University Press. 
Like other Aristotelian works, De generatione et corruptione only received its present form at some point in the first century $\mathrm{BC}$ with the edition of Andronicus of Rhodes. ${ }^{4}$ In the older literature, much has been made of Andronicus' activities as the editor or even creator of the Aristotelian corpus of texts, but Jonathan Barnes has recently urged us to be more cautious. On the basis of a new examination of all the relevant ancient sources Barnes concludes that Andronicus' arrangement of Aristotle's lecture notes and of the reports of his lectures are not of the same order as, for instance, Porphyry's edition of Plotinus' works. Instead, according to Barnes, Andronicus merely "tidied up" the overall structure of the treatises, and his editorial work is best characterized as "amateur tinkering." 5

The authenticity of De generatione et corruptione is beyond dispute. Its composition has been generally ascribed to the period when Aristotle resided in Lesbos and Macedonia, c. 347 to 335 BC. None of the Greek mansucripts in which De generatione has survived, among them the famous Parisian codex graecus 1853, goes, however, back further than the tenth century. In ancient catalogues such as Ptolemy's, De generatione et corruptione appears just after the Physica and the De caelo and is followed by the Meteorologica. ${ }^{6}$ This order is systematic and didactic, rather than that it reflects the order of writing. In any case, the opening passage of the Meteorologica indicates that these four works were considered to form a coherent unity:

\begin{abstract}
We have already discussed the first causes of nature, and all natural motion, also the stars ordered in the motion of the heavens, and the corporeal elements - enumerating and specifying them and showing how they change into one another - and becoming and perishing in general. There remains for consideration a part of this inquiry which all our predecessors called meteorology. ${ }^{7}$
\end{abstract}

Starting with the Physics, which examines in books 1 and 2 the causes of nature and in books 3-8 natural motion in all its aspects, Aristotle subsequently dealt with the celestial motions in De caelo, books 1 and 2, and the number and nature of the bodily elements in De caelo, books 3 and 4. "Becoming and perishing in general" is an adequate description of Aristotle's concerns in De generatione et corruptione as they are defined in its opening lines:

Our task is now to pick out the causes and definitions of generation and corruption common to all those things which come to be and perish in the course of nature; and secondly to investigate growth and alteration, asking what each of them is, and whether we are to

4. The date of Andronicus' activities is controversial. See Moraux, Der Aristotelismus, pp. 45-58, for an early dating and Barnes, "Roman Aristotle," pp. 21-24, for a later dating.

5. Barnes, "Roman Aristotle," p. 65. See also Moraux, Der Aristotelismus, pp. 62-63, who argued that Aristotle's texts were not a pile of unorganized notes before Andronicus.

6. Moraux, Der Aristotelismus, p. 86.

7. Cf. Aristotle, Meteorologica, 338a20-338b20. The translation is borrowed from The Complete Works of Aristotle (Barnes), Vol. 1, p. 554. 
suppose that the nature of alteration and generation is the same or different, as they are certainly distinguished in name. ${ }^{8}$

As usual, Aristotle starts his investigations with a survey of the views of some of his predecessors. He divides them into two categories; there are those who explain the multitude of appearances in the world by one underlying substance, and those who attribute it to a multitude of separate substances. The former deny the reality of generation and reduce it to alteration, that is, to qualitative changes of this one substance. The latter, among whom the Atomists, consider generation and corruption as the aggregation and segregation of elementary bodies. ${ }^{9}$

According to Aristotle, generation should not be identified with alteration; they are different types of change. At the same time, he disagrees with the Atomists and other pluralists, denying that generation and corruption amount to the aggregation and segregation of elementary substances: "generation cannot possibly be aggregation — not of the sort some people say it is." 10 Aristotle's rejection of this view is founded on his rejection of the essential atomist assumption that "the primary existences are things which have size and are indivisible." 11 The remainder of chapter 2 is therefore devoted to infinite divisibility. The essay by John Murdoch in the present volume is devoted to the medieval, and, to a lesser extent, the Renaissance fortuna of the arguments ascribed to Democritus in support of the position so fiercly combatted by Aristotle.

Next, Aristotle proceeds to develop his own notion of generation or coming to be. First, he analyses the ambiguity between "unqualified coming to be" and "coming to be something from being something," or, in modern usage, the difference between "to be" as existential verb and as copula. ${ }^{12}$ One of the main problems Aristotle has to tackle is the ancient maxim that "nothing can come to be out of nothing" which seems to be contradicted by his own view that substances can come into being. He has already dealt with this view in the Physics, but now returns to it. ${ }^{13}$ The maxim goes back to the Eleatic philosophers Parmenides and Zeno, who maintained that none of the things that exist come into being or pass away, or, in other words, that change is only apparent. According to Aristotle's report, they had argued that what comes to be must either do so from what already is, in which case it is no veritable coming to

8. Aristotle, De generatione et corruptione, 314a1-6. The translation is borrowed from Williams, p. 1.

9. Aristotle, De generatione et corruptione, 314a7-15, and Physica 187a11-26.

10. Aristotle, De generatione et corruptione, 317a30-32.

11. Aristotle, De generatione et corruptione $315 \mathrm{~b} 26-27$. The translation is borrowed from Williams.

12. Especially Williams, in the introduction to his Aristotle, De generatione et corruptione, pp. xi-xvi, has developed this aspect.

13. Aristotle, De generatione et corruptione, 317b13, which refers to Physica, I, 6-9. 
be, or from nothing at all. The latter option, however, seemed absurd. On these logical grounds they denied that change was possible.

In the Physics, Aristotle starts from the commonsense assumption that perceived change is real. With the help of his doctrine of form and matter, he then tries to solve the logical impasse. He considers the objects in the world as composites of underlying matter and imposed form. From the perspective of matter, change involves continuation. The underlying substrate does not change. From the perspective of form, however, change involves real change, because it consists of the successive replacement of one form by another. In Aristotle's view, the replacement of one form by another is not a transition from non-being to being, but rather a passage from potential being to actual being. Thus, matter is the cause of the perpetuity of generation and corruption. Generation is therefore not a coming to be out of what is not, and corruption is not the passing of things into nothing.

In chapters 4 and 5 of book 1 of De generatione et corruptione, Aristotle discusses two other types of change, namely alteration and growth. Both can be characterized as accidental changes, whereas generation and corruption are substantial changes. Alteration is a change from one contrary to the other in respect of "affection and quality." Growth, on the other hand, is change in respect of quantity or size. Moreover, it involves a special change of place, namely expansion.

Chapters 6-10 are preparing the ground for Aristotle's discussion of the elements in book 2. They are devoted to a few related concepts, such as what it is for things to act on one another (actio), to undergo action (passio), and to mix. In addition, Aristotle examines "contact" which is implied by the interaction of the elements.

Book 2 examines the causes of generation and corruption. They are the elements which by mixing constitute the substances. The elements correspond to the two fundamental pairs of contrarieties: wet-dry, and hot - cold. All other qualities can be reduced to these tangible qualities. Each of the elements earth, fire, air, and water is constituted by a pair of the fundamental qualities. Fire, for instance, is hot and dry, whereas air is hot and wet. Since each element contains a contrary quality, they can change into each other. None of the elements is primary.

The elements correspond to the two fundamental pairs of contrarieties: wetdry, and hot - cold. All other qualities can be reduced to these tangible qualities. Each of the elements earth, fire, air, and water is constituted by a pair of the fundamental qualities. Fire, for instance, is hot and dry, whereas air is hot and wet. Since each element contains a contrary quality, they can change into each other. None of the elements is primary.

Book 2 is rounded off with a discussion of necessity in the world of generation and corruption. For according to Aristotle, the succession of generations 
and corruptions is indeed necessary. He attributes the necessity of this cycli$\mathrm{cal}$ process to the circular movement of the sun. In the realm of individual generations and corruptions, however, there is no absolute necessity, but only conditional necessity. A generation is necessary in view of certain conditions which first need to be fulfilled.

As is the case with almost anything that Aristotle has written, the interpretation of many aspects of his views in De generatione et corruptione have come to be the subject matter of some debate. In particular his theories of prime matter, of mixture, and of necessity and contingency have received the attention of contemporary scholars. ${ }^{14}$ But the process of interpreting His Master's voice started already in Greek Antiquity.

\section{The Greek commentary tradition}

Only few commentaries on De generatione et corruptione by Greek commentators have survived: one by Philoponus, and through it, fragments of Alexander of Aphrodisias' lost commentary on De generatione et corruptione; and further Alexander's De mixtione, which discusses themes from Aristotle's De generatione et corruptione and in particular his theory of mixture. ${ }^{15}$

The articles by Frans de Haas and Henk Kubbinga in the present volume address this Greek tradition and in particular its response to problems that were raised by Aristotle's account of mixture in De generatione et corruptione book 1 , chapter 10. Their discussions include authors such as Simplicius and Themistius who treated these problems in their commentaries on other works by Aristotle.

As is well known, Aristotle distinguishes mixing (mixis) from two other processes, namely generation and corruption, and mechanical mixing or composition (synthesis). Both distinctions have raised a number of problems for subsequent commentators. The first distinction raises questions concerning the existence of the ingredients, whereas the second raises questions about their nature. According to Aristotle, the main contrast between mixing (mixis), on the one hand, and generation and corruption, on the other, is that the ingredients in a mixture somehow survive, whereas in corruption the ingredients

14. Cf. Lewis' contribution on Aristotle's notion of mixture in Lewis e.a. (eds.), Form, Matter, and Mixture; Richard Bemelmans, for instance, has questioned the tradition which attributes to Aristotle the notion of prima materia as utterly formless. See Bemelmans, Materia prima in Aristoteles, esp. pp. 168-204 and 338-393, which deal with passages in De generatione et corruptione. See further De Haas, John Philoponus' New Definition, which analyses Philoponus' concept of prime matter and its relation to the ancient commentary tradition. Necessity and contingency are discussed in Williams, in his Aristotle, De generatione et corruptione, pp. 199-203.

15. Ever since the start of Richard Sorabji's project of translating the Greek commentators into English and of providing their works with a philosophical analysis, the interest in these texts has undergone a revival. Over more than thirty volumes have appeared by now, among them C. J. F. Williams' posthumously published partial translation of Philoponus' commentary. Cf. Philoponus, On Aristotle. 
perish. More specifically, the ingredients in a mixture are not destroyed, but remain in the mixture in potentiality and are capable of being separated again (327b23-30). But what does it mean to say that the ingredients are preserved in potentiality if a mixis is a genuine unity sharply contrasted from synthesis, an aggregate? And of what kind of potentiality is Aristotle talking here: that of the elementary qualities of the ingredients, or that of their forms? Frans de Haas, in this volume, investigates Philoponus' discussion of these problems and sets it off against the views of Alexander of Aphrodisias, Proclus, and Simplicius. Moreover, he compares their genuine views with those that were attributed to them by Jacopo Zabarella in De mistione, which constitutes a chapter of his De rebus naturalibus.

Aristotle's distinction between mixis and synthesis raises puzzles about the nature of their respective ingredients. In his discussion of the cases where mixing in the proper sense (mixis) occurs, Aristotle rejects two alternative accounts (327b31-328a18). According to the first account, mixing occurs when "pieces" of different ingredients are "placed side by side in such a way that each of them is not apparent to perception." 16 Aristotle refutes this view, for it identifies "being mixed" with aggregation for those who, like Lynceus, with their penetrating glance can perceive that mixtures are actually heaps of particles. ${ }^{17}$ The second account claims that mixing occurs when the smallest possible parts of two ingredients are "arranged in such a way that every single part of either of the things mixed is alongside some part of the other." 18 Aristotle rejects this view on the grounds that a division into smallest possible particles is impossible.

In his article, Henk Kubbinga claims that Aristotle's discussion of these alternative views contains an inconsistency. For on the one hand, he denies that a body can be divided into its smallest parts (elachista), and yet, on the other, he claims that a mixis results precisely in a mixture of which every part is of the same nature as every other and as the whole. Taking his lead from a few brief remarks in Andreas van Melsen's classical study on the history of atomism, Kubbinga follows the fortune of the concept of elachiston, the Greek equivalent of minimum, in the Greek commentary tradition. ${ }^{19} \mathrm{He}$ believes that Philoponus' notion of elachiston as a substantive unity was an important step of the conceptual development towards the molecular theories in the seventeenth century, such as those formulated by Isaac Beeckman and Sébastien Basson.

16. Aristotle, De generatione et corruptione, 327b33-34, as translated by Williams.

17. The image of the sharp-eyed Lynceus and its role in seventeenth-century discussions of the microscope and telescope is discussed in Lüthy "Atomism," pp. 6-13.

18. Aristotle, De generatione et corruptione, 327b36-328a 2 as translated by Williams.

19. See Van Melsen, From Atomos to Atom, pp. 47-48. 


\section{The Latin Translations}

By the end of the twelfth century, the majority of Aristotle's works had been translated into Latin. The Latin translations furnished the conditions of the development of natural philosophy in the universities of Western Europe during the Late Middle Ages. The full significance of the response to Aristotle's libri naturales - and to his other works as well, for that matter - in the West can be better understood with the help of A. I. Sabra's terminology of "appropriation" and "naturalization." 20 Appropriation and naturalization imply that the transmission of Aristotle's works was more than merely a chapter in the history of the preservation of the Classical tradition. The translation movement represents the process of appropriation, which was a decidely active process: the Greek science and philosophy were not pressed upon the Latin West. ${ }^{21}$ The commentary literature represents the process of naturalization. Over time, the imported Greek knowledge came to be totally absorbed and thoroughly transformed in its new Latin context, even in such a way that the Western culture became its new natural home.

The translations of De generatione et corruptione occupied a regular place in the distinct waves of Latin translations of Aristotle. ${ }^{22}$ The first wave, which lasted from the end of the fourth until the beginning of the sixth century, only included translations of two of Aristotle's logical treatises, the Categories and De interpretatione. During the second wave, however, from the beginning of the twelfth until the end of the thirteenth century, De generatione et corruptione was translated twice. The first translation was made from the Arabic by Gerard of Cremona. This translation was soon superseded by one that was made directly from the Greek and which was edited in $1972 .{ }^{23}$ The Greco-Latin translation was, for a long time, considered anonymous or was attributed to Henry Aristippus. Only a couple of years ago, the translator was correctly identified as Burgund of Pisa. The intricate story of this whodunit and the new light it sheds on the transmission of De generatione et corruptione to the West, is discussed by James Otte in the present volume.

On the basis of manuscript evidence, even a third translation of De generatione et corruptione has been introduced in the scholarly literature, a translatio nova, tentatively attributed to William of Moerbeke. It is not certain at all, however, whether this version is really a distinct translation or revision, rather than a variant redaction of Burgund of Pisa's translation. ${ }^{24}$

20. Sabra, "The Appropriation." Note that Sabra developed this terminology to describe the influx of Greek science into the Islamic world.

21. This aspect is also emphasize, for instance, by Lohr, "The Medieval Interpretation of Aristotle," pp. $82-84$.

22. A convenient survey of the distinct translation movements of Aristotle's works is provided by Minio-Paluello, "Aristotle: Tradition and Influence" and further in Dod, "Aristoteles Latinus."

23. Aristoteles, De generatione et corruptione (Judycka).

24. See, for instance, Dod, "Aristoteles Latinus," p. 76. Lorenzo Minio-Paluello, however, has 
The third wave of translations ran from about 1400 until 1600 and was connected with the humanist movement. This is the least studied phase of the Latin translations. ${ }^{25}$ In general, the translations of this period are marked by a new approach towards Aristotle's texts. The medieval literal verbum e verbo renderings were replaced by more elegant versions. Geographically, the new translators were located in Italy and in France. During this period, De generatione et corruptione saw the appearence of new translations by George of Trebizond, Andronicus Callistus (not printed), Pietro Alcionio, Agostino Nifo, Flaminio Nobili, Joachim Périon with revisions by Nicholas of Grouchy, François Vatable, and Juan Ginés de Sepúlveda. ${ }^{26}$ Note, however, that the otherwise prolific Joannes Argyropulos did not leave us a translation of De generatione et corruptione.

In addition to Aristotle's own treatises, a number of his important Arabic and Greek commentators were also translated, who will be briefly considered here. Knowledge of the Greek commentaries was only fragmentary in the Latin West. Very few texts were known during the Middle Ages, and there was no commentary on De generatione et corruptione among them. Most of the extant commentaries became available in Latin only in the sixteenth century. ${ }^{27}$ Until that time, the Greek commentators were only known indirectly, through the intermediary of Arabic sources that had been translated into Latin, notably Avicenna and Averroes. ${ }^{28}$ In the case of De generatione et corruptione, Averroes seems to have been the most influential source. His Middle Commentary, a paraphrase of Aristotle's text written in 1172, was translated into Latin in the thirteenth century by Michael Scot. The Latin version of Averroes' Epitome, a short compendium, of De generatione et corruptione (translated from the Hebrew by Vital Nissus) is from a much later date. It was included in the 1550 Junta edition of Averroes' works. ${ }^{29}$

voiced convincing reservations against the existence of a distinct translatio nova of Aristotle's De generatione et corruptione by William of Moerbeke. See Minio-Paluello, "Henri Aristippe," reprinted in Opuscula, pp. 71-83. But see Judycka, "L'attribution."

25. See Schmitt, Aristotle and the Renaissance, pp. 64-88.

26. See Cranz, A Bibliography, p. 176, and further Schmitt, Aristotle and the Renaissance, pp. 134-148, for short biographical information about these translators. Trebizond's activities as a translator of De generatione et corruptione are discussed in Monfasani, George of Trebizond, pp. 58-59. Biographical information about Callistus is provided in Perosa, "Inediti." Callistus' translation has been preserved in the MS Firenze, Biblioteca Medicea Laurenziana, Plut. 84, 2.

27. The medieval Latin translations of the Greek commentators are being edited in the series Corpus Latinorum Commentariorum in Aristotelem Graecorum. Renaissance translations into Latin of the Greek commentators are reprinted in a new series founded by C. H. Lohr and published by Fromann Holzboog in Frankfurt: Commentaria in Aristotelem Graeca, versiones Latinae.

28. See, for instance, Gutras, Avicenna and the Aristotelian Tradition, pp. 289-290.

29. See Kurland, in the intoduction to his Averroes, on Aristotle's De generatione et corruptione, pp. xi-xiv, and further Cranz, "Editions," p. 125. Averroes' Middle Commentary has been edited in Averroes, Commentarium medium in Aristotelis De generatione et corruptione libros (Fobes e.a.). 
The low impact of Avicenna in the study of De generatione et corruptione is implicitly confirmed by Simone van Riet's essay in the present volume. Avicenna devoted the third treatise of his Kitab al Shifa, a philosophical encyclopedia, to a discussion of Aristotle's De generatione et corruptione. ${ }^{30}$ It was translated into Latin in 1280. As Simone van Riet pointed out, the influence of Avicenna's treatise before 1280 can therefore only have been through intermediaries. Its influence after 1280 , such as, for instance, in the fourteenth-century discussions on mixture, may have been direct, but still needs further investigation. The sole surviving Latin copy of Avicenna's Liber tertius naturalium de generatione et corruptione dates from 1480.

\section{The Latin Commentary Tradition}

The related but distinct process of naturalizing Aristotle, to return once more to Sabra's terminology, started only in the thirteenth century. Even though by the end of the twelfth century most of his works had been translated into Latin, they came only slowly into circulation. The year 1255 is usually taken as a dramatic turning point in the world of medieval learning. In that year, the arts faculty at Paris passed legislation which prescribed the study of all known works by Aristotle to all students. Other universities too introduced or had already introduced his works into their curricula. For the next four hundred years, they came to be routinely studied and commented upon at all the centers of learning from Messina to Uppsala and Saint Andrews, and from Coimbra to Dorpat. The introduction of Aristotle's works into the curriculum created three new domains of philosophy: moral philosophy, metaphysics, and natural philosophy. The latter was variously designated as scientia naturalis, physica, philosophia naturalis, and, in the post-medieval period, as physiologia. The main vehicle by which Aristotle's ideas were mastered, assimilated, and further developed was the commentary literature. Up until the seventeenth century, its history runs parallel to the history of science.

Aristotle's "natural books" (libri naturales) constituted the core of natural philosophy. The Physics was the most important text. It was understood to provide a characterization of the most general principles and properties of natural entities, that is to say, entities that thanks to an inner source were capable of changing. The other libri naturales, such as De Caelo, De Anima, De generatione et corruptione, Meteorologica, and the Parva naturalia were arranged around the Physics as treatises that discussed particular aspects of natural objects. The place of De generatione et corruptione within the university curriculum has received little attention. The treatise was taught at Paris and Oxford, at Pisa and Padua, both by ordinary and extraordinary professors, and at the

30. Avicenna, Liber tertius naturalium (Van Riet). 
Collegio Romano, but many aspects still need to be investigated, in particular the remarkable growth of commentaries which the Renaissance experienced. ${ }^{31}$

The exploration of the commentary tradition on this treatise has fared only slightly better. Editions have appeared of the commentaries by Giles of Orléans, Albert the Great, Thomas Aquinas (which was finished by Thomas of Sutton), Boethius of Dacia, and Nicholas Oresme. ${ }^{32}$ Recently, Stefano Caroti has suggested that the quaestiones literature on De generatione et corruptione may have had their (remote) origin in Albert the Great's digressiones in his own paraphrase of that text. ${ }^{33}$

So far only few doctrinal aspects of the commentary tradition have been studied. Most attention has been devoted to the commentaries on De generatione et corruptione that were produced by the so-called Buridan School, that is, John Buridan, Albert of Saxony, Nicholas Oresme, and Marsilius of Inghen. In a classical study, for instance, Anneliese Maier has examined their respective views on the problem of mixtio, thereby uncovering also important information about the medieval mansucripts in which their texts have been preserved. ${ }^{34}$ Joan Cadden has studied Albert of Saxony's and Marsilius of Inghen's theories of biological growth (augmentatio) and has compared them to those of Albert the Great and Thomas Aquinas. ${ }^{35}$ Henk Braakhuis has edited John Buridan's quaestio on whether a body that has been destroyed can return as numerically the same, and examined its philosophical context. ${ }^{36}$ Stefano Caroti wrote an exhaustive study of the discussion of reactio, that is, the interaction between agent and patient in an action, by the Buridan school, and has provided an extensive survey of the topics that are discussed in Nicholas Oresme's Quaestiones on De generatione et corruptione. ${ }^{37}$

The trend to focus research on what, by lack of any better term, will continue to be called the "Buridan School," is also apparent in this volume. Jürgen

31. See note 2, and further Wallace, "Traditional Natural Philosophy," pp. 212-213.

32. Aegidius Aurelianensis, Quaestiones super De generatione et corruptione (Kuksewicz); Albertus Magnus, De generatione et corruptione (Hossfeld); Thomas Aquinas, In Aristotelis libros De caelo et mundo, De generatione et corruptione, Meteorologicorum expositio (Spiazzi); Thomas de Sutton, De generatione et corruptione (Kelley); Boethius Dacus, Quaestiones De generatione et corruptione (Sajó); Nicolaus Oresmius, Quaestiones super De generatione et corruptione (Caroti). A critical edition of Marsilius of Inghen's Quaestiones in libros De generatione et corruptione is being prepared by Thijssen.

33. Caroti, "Note."

34. Maier, An der Grenze, esp. pp. 118-137. Maier's suggestion that Nicole Oresme was the author of the commentary on De generatione et corruptione preserved in MS Città del Vaticano, Biblioteca Apostolica Vaticana, Vat. lat. 3097 was refuted in Thijssen, "Buridan." See also Michael, Johannes Buridan, II, pp. 631-648.

35. Cadden, The Medieval Philosophy and Biology of Growth. Albert the Great's commentary is, furthermore, studied in Hossfeld, "Grundgedanken."

36. Braakhuis, "John Buridan."

37. Caroti, “Da Buridano,' and Nicolaus Oresmius, Quaestiones super De generatione et corruptione (Caroti), pp. 13*-199*. 
Sarnowsky surveys the main themes that are discussed in Albert of Saxony's commentary on De generatione et corruptione. Interestingly, Albert's commentary is not preceded by a typical preface which indicates the position of the treatise in the larger framework of natural philosophy. Instead, Albert only observes that De generatione's subject is the ens mobile ad formam and then proceeds to list its four main topics, i.e. generation and corruption, augmentation, alteration, and mixture. ${ }^{38}$ According to Sarnowsky, Alberts' De generatione commentary has the character of an appendix to his Physics.

As Sarnowsky observes, it was printed ten times, while only three manuscripts have survived. The printed editions are all derived from the Padua edition of 1480 , and were mainly distributed in Italy. There were two Parisian editions. In the Italian editions, Albert's texts is printed together with the commentaries by Giles of Rome and Marsilius of Inghen. It is noteworthy that the dissemination of Marsilius' commentary shows a somewhat different pattern. In addition to the many printed editions, Marisilius' text has been preserved in over twenty manuscripts, most of which are of Italian origin. Moreover, some of his views were literally quoted in (Italian) debates that took place in the fifteenth and sixteenth centuries. ${ }^{39}$

Stefano Caroti investigates the commentary by Nicholas Oresme, more in particular the latter's views on individuation and the related notions of contingency and necessity in the causal order. Oresme's discussion is focused on the numerical distinction of natural effects in the causal order, which takes place through time: every effect is generated at a different instant.

The essay by Henk Braakhuis is devoted to a problem addressed by John Buridan at the opening of his commentary on De generatione et corruptione, namely how it is possible to have certain knowledge (scientia) about things that have ceased to exist. Buridan takes a semantic approach to this problem and introduces the terminology of suppositio naturalis to deal with the meaning of terms that refer to empty classes. Braakhuis studies both versions of Buridan's commentary and presents an edition of the relevant passages in an appendix.

Silvia Donati nicely complements Henk Braakhuis' paper, for she examines thirteenth-century views on scientific knowledge about things that are (temporarily) non-existent. Donati pays special attention to the Expositor, Giles of Rome (who was also often quoted by Buridan), and investigates his influence on thirteenth-century authors, both at Oxford and Paris.

38. Such a preface is provided by John Buridan in his Quaestiones super libros De generatione et corruptione. It offers a division of natural philosophy, identifying two basic types of change in Aristotle's libri naturales: local change (ad ubi) and change involving the substantial form (ad formam). The latter's general principles are precisely discussed in De generatione et corruptione. Buridan's prologue has been edited in Thijssen, Johannes Buridanus, vol. 2, pp. 118-121.

39. Thijssen, "The Circulation." 
The final essay in this volume, written by Anita Guerrini, tackles Robert Boyle's attitude toward the Aristotelian tradition. The corpuscularian Boyle is usually remembered as one of the figure-heads of the mechanical philosophy, which, according to traditional historiography, was radically opposed to Aristotelianism. As a matter of fact, however, Boyle's attitude toward the Aristotelian heritage was more complex. In spite of his criticism, in the The Origin of Forms and Qualities, of Aristotelian natural philosophy, he could not entirely disengage himself from its terminology of forms, matter, qualities, and mixture. ${ }^{40}$

Ironically, with the corpuscularian philosophy of the seventeenth century, of which atomism was a variant, we have come to a full circle. It was precisely the Atomists that Aristotle had attempted to refute at the beginning of his De generatione et corruptione and whose doctrine of generation - which in Aristotle's view was more correctly characterized as aggregation - he replaced by his own theory of matter and form. In the seventeenth century, it was the atomists who, rightly or wrongly, believed to have refuted Aristotelian hylemorphism. The role of the commentary tradition on De generatione et corruptione in this complex history has not yet received due recognition, nor many other of its aspects, as this brief survey has tried to show. ${ }^{41}$

40. The complexity of the interaction between hylemorphism and atomism, certainly on a terminological level, is clearly illustrated in Newman e.a. (eds.), The Fate of Hylemorphism, more in particular in Stephen Clucas' contribution "The Infinite Variety of Formes and Magnitude," pp. 268-271. See further Newman, "The Alchemical Sources" which points at Boyle's debt to the Aristotelian view that the ingredients of a mixture can be fully recovered. In particular Daniel Sennert was an important source, as has been elaborated by William Newman in two unpublished papers. Both Sennert and Boyle merged Aristotle's theory of mixture, as explained in De generatione et corruptione, with atomism. See further Emerton, The Scientific Reinterpretation, which is one of the few attempts at a diachronic study of the concept of form and its transformations from Aristotle up until eigthteenth-century crystallography.

41. Research for this article was financially supported by a grant (200-22-295) from the Netherlands Organization for Scientific Research (NWO). I am particularly grateful to Frans de Haas, Cees Leijenhorst, and Christoph Lüthy for their comments on an earlier version of this article. 